\title{
DWOISTOŚĆ DOŚWIADCZENIA: GRUZJA W DYSKURSIE POSTKOLONIALNYM O POSTSOWIECKOŚCI*
}

\author{
DUALITY OF EXPERIENCE: GEORGIA IN POSTCOLONIAL \\ DISCOURSE ABOUT THE POST-SOVIET
}

Bartłomiej Krzysztan**

\begin{abstract}
ABSTRAKT
Pytanie badawcze tekstu sprowadza się do rozważań nad możliwością aplikacji teorii postkolonialnych w przypadku postsowieckiej Gruzji. Krytyka postkolonialna niemal ominęła sferę postsowiecką, pozostawiając ogromną przestrzeń polityczną w monopolu idei interpretacji przez badania systemowo-tranzycyjne. Przez rozważania nad potencjalnymi limitacjami dla możliwości przepisania teorii w odmiennych uwarunkowaniach politycznych autor próbuje rozwinąć szerszą perspektywę dla interpretacji socjopolitycznych procesów w postsowieckiej Gruzji. Przypadek Gruzji jest interesujący dla teorii postkolonialnych, gdyż zgodnie z hipotezą Gruzja podlega dwoistości postkolonialnego
\end{abstract}

The article is trying to answer the question whether the application of postcolonial theories is possible when the example of Post-Soviet Georgia is taken into consideration. Postcolonial critique almost avoided the former Soviet Union, leaving the huge cultural space with the lack of diversified approach. Through the analysis of potential limitations for re-writing of the theory in other political circumstances, the author attempts to develop the broader background for the interpretation of sociopolitical processes in the PostSoviet Georgia. The case of Georgia is interesting because of the possible hypothesis that Georgia as postcolonial entity faces the experience of duality. Georgia faces up the multi-layered obstacles

* Tekst powstał w rezultacie badań terenowych przeprowadzonych w Armenii, Gruzji i Abchazji w lecie 2013 roku dzięki grantowi wewnętrznemu Wydziału Nauk Społecznych Uniwersytetu Wrocławskiego. Uzupełniony został o materiały zebrane podczas dwuletniego pobytu badawczego w International School for Caucasus Studies na Ilia State University w latach 2014-2016. Oba granty badawcze służą zebraniu. materiałów do pracy doktorskiej, której istotną częścią jest teoretyczno-metodologiczna analiza praxis postkolonialnego na Kaukazie Południowym.

** Polska Akademia Nauk w Warszawie, Instytut Studiów Politycznych. 
doświadczenia. Z jednej strony podlega procesom dependencyjnym ze strony byłego hegemona, $\mathrm{z}$ drugiej $\mathrm{w}$ ten sam sposób (jako kolonialny dzierżawca przemocy) postrzegana jest przez mniejszości etniczne w „lokalnym” imperium. Zatem, używając nomenklatury postkolonialnej, tekst stara się zredefiniować transformacyjne i postkolonialne doświadczenie Gruzji.

Słowa kluczowe: postkolonializm, Gruzja, dekolonizacja umysłów, konflikty postsowieckie connecting with political and cultural heritage of Russification, but also is treated as the colonizer by the ethnic minorities. Therefore, using postcolonial nomenclature, paper is trying the redefine the transformational and postcolonial experience of Georgia.

Keywords: postcolonialism, Georgia, decolonization of minds, Post-Soviet conflicts

\section{WSTĘP}

Vitaly Chernetsky, opisując podejścia konceptualne i metodologiczne do postsowieckości i postsocjalizmu, stwierdził, że „(...) postkolonializm jest prawdopodobnie jedynym wielkim współczesnym dyskursem, który w dużej mierze jest, z dumą i uporczywie, ignorowany [w sferze postsowieckiej - aut.] (stare imperialne nawyki umierają długo $(2007, \text { s. } 43)^{1}$. Od umownego początku akademickiego zainteresowania postkolonializmem, a więc publikacji Orientalizmu Edwarda W. Saida w 1979 roku $(1979,2005)$, teorie postkolonialne wykraczają mocno poza pierwotny obszar zainteresowań, a więc dziedzictwo kolonializmu brytyjskiego i francuskiego. Jest to ekspansja nie tylko metodologiczna i teoretyczna w dyscyplinie pierwotnej, ale również ekspansja ponaddyscyplinarna oraz geograficzna i polityczna. Wywodzące się z badań literackich, wędrujące pojęcia ekspansywnie odżegnują się od dyscypliny (która ma tu podwójne znaczenie - akademickie, ale także dyscyplinujące, dyskursywnie przemocowe, a więc regresywne) (Bal \& Marx-MacDonald, 2002). O potrzebie przekraczania w celu budowania globalnej krytyki postkolonialnej pisał David Chioni Moore, nawiązując również do sfery postsowieckiej (Chioni Moore, 2001). Chernetsky, pisząc o pominięciu postsowieckości, wyolbrzymił braki aplikacji teorii postkolonialnych $\mathrm{w}$ badaniach postsowieckości. $\mathrm{W}$ ostatnich latach pojawiło się sporo wartościowych prac, również tworzonych przez polskich badaczy (Beauvois, 2005; Beinorius, 2013; Broers, 2008; Chernetsky, 2007; Condee, 2009; Etkind,

1 Tłumaczenie własne. Co ciekawe, chwilę wcześniej Chernetsky wspomina jako jedną z niewielu prób tego sposobu widzenia Trubadurów Imperium E. Thompson, stwierdzając eufemistycznie, że książka jest „forsowna, ale wadliwa” (Thompson, 2000). 
2011; Janion, 2003; Kuzio, 2002; Michaels, 2004; Morozov, 2015; Racevskis, 2005; Riabczuk, 2015; Smola \& Uffelmann, 2016; Sowa, 2011; Thompson, 2000; Todorova, 2008; Uffelmann, 2013; Zarycki, 2014). Niemniej wydaje się być słuszne stwierdzenie, że jest to marginalnie podejmowana dyskusja, szczególnie w naukach politycznych, oraz że wiele jeszcze problemów badawczych może zostać poddanych analizie za pomocą narzędzi teoretycznych wypracowanych w $\mathrm{PT}^{2}$. Odpowiedź na pytanie, skąd bierze się to istotne, często celowe pominięcie, było już podejmowane (Zob. m.in.: Adams, 2008; Hladík, 2011; Krzysztan, 2016; Tlostanova, 2012, 2015a, 2015b).

Dyskusja nad pominięciem nie jest jednak podstawowym celem tego tekstu. Stanowi go z kolei problem badawczy, którym jest próba przybliżenia potencjału aplikacji teorii postkolonialnych w badaniach postdyscyplinarnych nad peryferiami byłego Związku Socjalistycznych Republik Sowieckich, ujęty w studium przypadku Gruzji. Hipoteza tej pracy jest następująca: w dyskursie postkolonialnym Gruzja poddana jest wieloznacznej dwoistości doświadczenia, będąc zarówno kolonizowanym, jak też kolonizującym. Hipoteza wynika z kilku uwarunkowań:

1. Gruzja była uzależniona politycznie, będąc peryferyjną częścią imperium (najpierw Imperium Rosyjskie, a potem ZSRS). W związku z tym pojawiły się typowe polityczne strategie postkolonialne (mimetyzm, kompradorstwo, dependencja strukturalna). [Dependencyjna postkolonialna dwoistość doświadczenia].

2. Obserwowalna jest strategia budowania narracji wyższości wobec byłego kolonizatora (zarówno polityczna, jak też cywilizacyjna i kulturowa). Pojawia się również antykolonialny nacjonalizm. [Narracyjna postkolonialna dwoistość doświadczenia].

3. Postkolonializm konfliktów zamrożonych w Abchazji i Osetii Południowej. Gruzja jako państwo kolonialne. Kultura gruzińska jako system przemocy [Schizoidalna postkolonialna dwoistość doświadczenia].

4. Gruzja postkolonialna jako państwo symbolicznie opresyjne. Polityczno-społeczna przemoc symboliczna wobec mniejszości etnicznych [Opresyjno-symboliczna postkolonialna dwoistość doświadczenia].

2 Aby się nie powtarzać, w każdym miejscu, gdzie przywoływać będę metodologie i teorie postkolonialne, używać będę skrótu PT (postcolonial theories). 
Postkolonializm cechuje się nieustannym rozszerzaniem i potencjalną możliwością dalszych podziałów, jak pisał sam Said (2005, s. 91). Wychodząc od tego założenia, pozostałości rosyjskiego, a potem sowieckiego imperium stanowić powinny inspirującą przestrzeń badawczą dla interpretacji postkolonialnej. Istnieje jednak kilka uwarunkowań, które - zdaniem części teoretyków - czynią tę refleksję mocno ograniczoną:

1. Obsesja Zachodu i tradycyjne zainteresowanie teorii krytyką „zachodnich" imperiów kolonialnych.

2. Marksistowskie i marksowskie źródła refleksji postkolonialnej (pozorna niechęć metodologiczna).

3. Niejasny podział między centrum i peryferiami („kontynentalnośç" i płynność imperium).

4. Struktura ZSRS (teoretyczny brak hegemonii jednej tylko nacji) i nieoczywistość kolonialnego hegemona i spadkobiercy.

5. Ideologiczność i polityczność postkolonializmu.

Jak postaramy się wykazać, każde $\mathrm{z}$ tych ograniczeń ma swoje odzwierciedlenie na jednym z poziomów postkolonialnego doświadczenia Gruzji. Poprzez próbę dialektycznego odrzucenia limitacji przeprowadzona zostanie analiza poszczególnych warstw podporządkowania.

Wychodząc od takich założeń, spróbujemy zbudować przyczynek teoretyczno-metodologiczny do pogłębionych badań dotyczących postkolonialnego doświadczenia Gruzji.

\section{DEPENDENCYJNA POSTKOLONIALNA DWOISTOŚĆ DOŚWIADCZENIA. POSTKOLONIALIZM POLITYCZNY}

W politologicznej perspektywie gruzińskiej sytuacji postkolonialnej wyróżnić można cztery najistotniejsze czynniki podległości (Gawrycki \& Szeptycki, 2012, ss. $212-224)^{3}$.

Gruzja była członkiem Wspólnoty Niepodległych Państw między rokiem 1993 a 2008, kiedy to po wojnie sierpniowej oficjalnie ją opuściła (Kakachia \& Minesashvili, 2015). Mimo skostniałego charakteru organizacji, jej istnienie jest

3 Gawrycki i Szeptycki wyróżniają jeszcze czynnik demograficzny, czyli wykorzystanie Rosjan mieszkających w byłych republikach sowieckich, jednak nie ma on znaczenia w przypadku Gruzji, stąd pominięcie. 
istotnym czynnikiem podkreślającym postkolonialne zależności (Zob. np. Brzezinski, Sullivan, \& D.C., 1997; Robson, 2006). Rola tejże może być porównana do statusu „brytyjskiej” Wspólnoty Narodów i Międzynarodowej Organizacji Frankofonii. Podobnie jak one, również WNP, nie posiadając formalnej struktury oddziaływania, pozostawiła nowo utworzone państwa w bezpośredniej zależności, zarówno ekonomicznej, jak i kulturowej. Jej ewoluująca forma, której zwieńczeniem ma być powstanie na całym terytorium postsowieckim Euroazjatyckiej Wspólnoty Gospodarczej, wskazuje na chęć wciągnięcia przez byłą metropolię dawnych peryferii w bezpośrednią strefę wpływów, zarówno ekonomicznych, jak i politycznych (Freire, 2008). Z perspektywy postkolonializmu na poziomie hard power istnienie takich projektów reintegracyjnych, mimo ich słabości, jest kluczowe. Poziom stosunków zależności pośrednio generowany przez podobne próby obrazuje przykład Gruzji, która starając się, po wojnie w 2008 roku, wyzbyć wszelkich dróg nacisku, w pierwszej kolejności zrezygnowała z członkostwa w organizacji. Zarówno w Moskwie, jak i w Tbilisi to działanie było interpretowane nie tylko przez pryzmat chęci powrotu do jedności z ideą Zachodu, ale konieczności zerwania więzów podporządkowania.

Konflikty w przestrzeni postsowieckiej po okresie radykalizacji procesów irredentyzmu i szowinizmu narodowego spowodowały wymuszony powrót do władzy byłych wysokich funkcjonariuszy sowieckiego aparatu władzy (kompradorstwo). Fiasko rządów Zwiada Gamsachurdii oraz wewnętrzna dezintegracja doprowadziły do restytucji Eduarda Szewardnadzego ${ }^{4}$, byłego pierwszego sekretarza Gruzińskiej SRS oraz ministra spraw zagranicznych ZSRS. Powrót nomenklatury do władzy jest typowy dla przestrzeni postkolonialnych. System sowiecki cechował się niską aktywnością opozycji, co w konsekwencji spowodowało brak kompetentnych elit po rozpadzie imperium. Pozorna stabilność doświadczonych aparatczyków była kuszącą perspektywą, która z czasem sprowadziła relację z byłym kolonizatorem do postaw politycznego mimetyzmu i kompradorstwa (Gawrycki \& Szeptycki, 2012, ss. 213-214). Przejęcie władzy przez Szewardnadzego wiązało się w Gruzji z decyzjami politycznymi, których głównym spoiwem była strategia wykorzystania siły byłej metropolii dla osiągnięcia wymiernych profitów (zakończenie wojny w Abchazji i wojny domowej). Było to zachowanie

${ }^{4} \mathrm{~W}$ tekście używam transliteracji języka gruzińskiego opracowanej przez prof. Andrzeja Pisowicza (http://ksng.gugik.gov.pl/pliki/latynizacja/gruzinski.pdf). W przypadku języka rosyjskiego używam transliteracji na podstawie Rozporządzenia Ministra Spraw Wewnętrznych i Administracji z dnia 30 maja 2005 roku w sprawie sposobu transliteracji imion i nazwisk osób należących do mniejszości narodowych i etnicznych zapisanych w alfabecie innym niż alfabet łaciński. 
status quo, będące jednak polityką regresywną. Stąd też brała się zbieżność działań Szewardnadzego z rosyjską racją stanu oraz podobny program ekonomicznych działań „reformatorskich” i usystematyzowana rola korupcji. Taki zdefiniowany sposób działania (bandwagoning) skutkował bezpośrednio określonymi limitacjami demokratycznych narzędzi, a finalnie doprowadził do kompromitacji skostniałego systemu i alternacji władzy w wyniku Rewolucji Róż ${ }^{5}$.

Polityka energetyczna i jej instrumentalne wykorzystanie jest elementem rosyjskiej polityki siły. Zgodnie z założeniami budowanie zależności energetycznej jest istotnym elementem regulowania stosunków z Gruzją. Tzw. polityka cenowa była wykorzystywana wielokrotnie wobec niepokornego działania prezydenta Micheila Saakaszwilego, w czarno-białych barwach postrzegającego relacje z Rosją i z Zachodem (polityka niebezpieczeństwa) (Pliszczyńska, 2010). Jakkolwiek energetyka jest główną kartą przetargową, służąca do temperowania antyrosyjskich i antykolonialnych nastrojów, to podobną neokolonialną ingerencję zaobserwować można także w innych obszarach gospodarki. Jest to typowo postimperialny sposób regulacji relacji z byłą kolonią bądź peryferiami.

Kolejną ingerencją w wewnętrzne sprawy Gruzji była obecność rosyjskich baz wojskowych. Był to podstawowy czynnik, pozwalający utrzymać „zamrożone” konflikty na terenie Gruzji przed wojną sierpniową. Jak słusznie stwierdza Nikolai Sokov, obecność baz militarnych jest typowa dla państw, w których Rosja nadal chce zachować wiodącą kolonialną rolę. Stąd też pragmatyczne szybkie wycofanie wojsk z państw satelickich w Europie Środkowej oraz z państw bałtyckich w celu zwiększenia wpływu na integralność terytorialną Kaukazu, Ukrainy, Białorusi, Mołdawii oraz Azji Środkowej. W przypadku Gruzji likwidacja baz jest działaniem jedynie pozornym. Poza wspomnianą już obecnością wojsk na terenie republik secesjonistycznych, kluczowe znaczenie ma także stałe podgrzewanie atmosfery wokół konfliktów. W Gruzji istnieje powszechna opinia, że gdyby nie kolonialny interwencjonizm militarny Rosji, sporne kwestie z Osetyjczykami i Abchazami udałoby się rozwiązać pokojowo i w krótkim czasie.

5 Mimo wszystko postać Szewardnadzego jest niejednoznaczna. Jego polityka wobec Rosji opierała się na wykorzystywaniu potencjału silniejszego sąsiada dla wymiernych korzyści.

6 Były to: Waziani, Achalkalaki i Batumi. Czwarta z dużych baz znajduje się na terytorium Abchazji w Gudaucie. Trudna do określenia jest rzeczywista ilość rosyjskich żołnierzy w Osetii Południowej i Abchazji (Sokov, 2005).

7 Wniosek wyciągnięty na podstawie ponad setki wywiadów przeprowadzonych w Gruzji w latach 2013-2016. Co ciekawe w Abchazji, mimo wzrastającej postawy antyrosyjskiej, ten wniosek o możliwej koncyliacji nie jest już tak oczywisty. 


\section{NARRACYJNA POSTKOLONIALNA DWOISTOŚĆ DOŚWIADCZENIA. KU DEKOLONIZACJI UMYSŁÓW}

Opisane powyżej czynniki strukturalne stanowią tylko fragment postkolonialnej krytyki. Trudniejsze do zdefiniowania są te elementy zależności, które określić należy mianem mentalnych (Spivak, 2006, s. 651), bowiem w autotelicznej „sferze [kultury - aut.] najtrudniej jest przeprowadzić dekolonizację" (Gawrycki \& Szeptycki, 2012, s. 159). Teoretycy antyzachodniego postkolonializmu wskazują na istotną rolę tego, co najtrafniej zdefiniował Ngugi wa T'hiong’o - dekolonizacji umysłów (2011). Związki peryferii z metropolią - zaczynające się od uzależnienia ekonomiczno-politycznego, które zostało opisane m.in. przez Lenina, wraz z procesami pogłębiania się zależności -- coraz wyraźniej oddziałują na poziom społeczny, a następnie przez swą permanentną obecność redefiniują wartości (1999). W przestrzeni postsowieckiej najpełniejszą próbą oddania procesów zmiany świadomościowego postrzegania jest semantyczna konstrukcja homo sovieticus, która ma jednak, ze względu na swój głęboko metaforyczny charakter, sporo mankamentów, jeśli używana jest do analizy procesów politycznych (Miłosz, 2009; Staniszkis, 2006; Śpiewak, 2005; Tischner, 1992; Zinoviev, 1984). Przyjrzyjmy się podstawowym elementom kulturowych zależności postkolonialnych, które zaobserwować można w Gruzji.

Po pierwsze - obsesja Zachodu, eksport idei i tożsamość wyjątkowości. Jest to pogląd oparty na interpretacji Zachodu przez pryzmat jego istnienia jako systemu opresyjnego. Dipesh Chakrabarty, wskazując na źródła podporządkowania, postuluje stopniową limitację zgubnego wpływu rewolucji kartezjańskiej i filozofii Oświecenia, które położyły intelektualną podstawę pod budowę relacji kolonialnych. Opiera się natomiast na ponowoczesnych i poststrukturalnych koncepcjach Szkoły Annales, Jacquesa Derridy i Michela Foucaulta (Chakrabarty, 2011, ss. 7-21). Ta dualność spojrzenia wtłacza perspektywę postkolonialną w uniwersalia, przez które całość doświadczenia przyjmuje negatywny wydźwięk, a jedyną ścieżką ucieczki jest odżegnanie się od traumy kolonializmu brytyjskiego czy francuskiego. W przestrzeni posowieckiej, w kontekście Gruzji, trudno mówić o jedynie negatywnym, zgubnym wpływie implementacji zachodnich idei. ZSRS nigdy nie budował tożsamości ideowej własnej ekspansji na wykorzystaniu osiągnięć scjentyzmu oświeceniowego i kartezjanizmu. Słuszność zdaje się mieć Josef Kroutvor, pisząc o ahistoryczności Wschodu (1998, s. 30). Idea „Zachodu” w całej historii państwowości Rosji pojawiła się jedynie epizodycznie, nigdy nie stanowiąc podstawy tożsamości kulturowej zarówno wśród 
elit, jak i tym bardziej na poziomie społecznym. Obsesja Zachodu w omawianym kontekście związana jest $\mathrm{z}$ budowaniem antykolonialnego nacjonalizmu, który wedle teorii Benedicta Andersona miał być tworzony w opozycji do źródeł kolonializmu, a więc kapitalizmu i Reformacji (1997, ss. 48-57) ${ }^{8}$. Stricte zachodnie idee pojawiają się w Gruzji w wyniku kolonializmu rosyjskiego, a mimo to (co neguje m.in. idea prometeizmu), antykolonialna tożsamość gruzińska opiera się na budowaniu narracji o znacznie głębiej powiązanej z Zachodem historii cywilizacji gruzińskiej, która została przerwana przez inwazję barbarzyńskiego Imperium Rosyjskiego.

Gia Nodia twierdzi, że w przypadku Gruzji można mówić o „eksportowanych” czynnikach tożsamości narodowej. Związane są one $\mathrm{z}$ aksjologią tradycyjnie przypisywaną Zachodowi. Chrześcijaństwo i hellenistyczne koneksje pozwalały na kulturową ciągłość w zderzeniu z imperializmem tureckim, arabskim i perskim. Jednocześnie przez definiowanie się w kontrze do „dzikiego orientu” skłaniały do poszukiwania połączeń z Zachodem (Nodia, 1998, s. 13; Zadura, 2010, ss. 281-287). W efekcie wykreowała się swoistość gruzińskich opowieści założycielskich, które podkreślały „pierwotność” Gruzji jako kolebki świata antycznego przez rozliczne kontakty władców Kolchidy i Iberii z antyczną Grecją (Janicki, 2009, ss. 105-106). Jednakże pomostem łączącym Gruzję z Zachodem była także imperialna Rosja. Redefinicja i rekonstrukcja świadomości i tożsamości narodowej u zarania niepodległościowego doświadczenia w XX wieku związana była w znacznej mierze $\mathrm{z}$ nacjonalistycznym i deterministycznym wobec mniejszości narodowych dyskursem. Wydarzenia w Gruzji po upadku ZSRS opierają się na typowych procesach irredentyzmu. Proces wyzwalania z oków kolonializmu kulturowego stał się polityką odbudowy tożsamości narodowej, opartą na wykluczających antagonizmach albo odrzuceniu'. Ostentacyjna wrogość skierowała się jednak nie tylko na zewnątrz, w stronę byłej metropolii, ale także do wewnątrz, w stronę mniejszości etnicznych. Pielęgnacja wartościującego modelu stratyfikacji doprowadziła do eskalacji typowo postkolonialnych konfliktów etnopolitycznych.

8 Dyskusję z Andersonem podjął m.in. Partha Chatterjee (1993, s. 3-13). Jakkolwiek część zarzutów wobec Andersona, z punktu widzenia PT wydaje się słuszna (np. dotycząca ahistoryczności i europocentryczności zagadnienia czasu), przypadek Gruzji lepiej wpisuje się w strukturę antykolonialnego (mentalnie) nacjonalizmu.

9 Przykładem takiego odrzucenia może być zmiana pierwszego języka obcego w gruzińskich szkołach. Pisał o tym m.in. Piotr Trzaskowski (2009, s. 118). 
Te narracyjne próby odrzucenia dziedzictwa zależności stanowią egzemplifikację strategii postkolonialnej. Są też podstawą do przekształcania dyskursu, co realizuje się w koncepcji tożsamości wyjątkowości (Falkowski, 2010, s. 182). Koncepcja ta podkreśla budowanie narracji o różnicy między byłym hegemonem i odradzającymi się peryferiami. Nie jest to odrodzenie wiązane ze zjawiskami pozytywnego nacjonalizmu (nation building processes), pomocnego w umacnianiu procesów narodowowyzwoleńczych, o których pisał m.in. Alberto Memmi (Memmi \& Sartre, 2013, ss. 95-96). Ten sposób wyzwalania się spod kulturowego jarzma pojawił się w Gruzji dopiero po Rewolucji Róż w 2003 roku. Taka percepcja procesów „budowy” związana jest z kwestiami języka i pamięci. Nutsa Batiaszwili zwraca uwagę na swoisty mitologiczny stosunek do bycia Gruzinem, oparty na pojęciu kartveloba (gruzińskość) (Batiashvili, 2012, ss. 186-200). Na tę kluczową dla rekonstrukcji tożsamości kwestię składają się dbałość o ochronę języka oraz zachowanie wspólnej pamięci, która jest traktowana jednoznacznie z historią. Jest to kontynuacja typowego dla całego Kaukazu Południowego instrumentalnego wykorzystania nauki historii, koniecznego dla potwierdzenia politycznych założeń. Zgodnie z ową ideą decyzją polityczną historia ma być spreparowanym tworzywem, które w odpowiedniej formie należy przekazać kolejnym pokoleniom (Batiashvili, 2012, s. 187). Podobny sposób interpretacji etniczności, wynikający z dwoistego doświadczenia kolonializmu, jest tradycyjną kontynuacją. Decyzja polityczna przez wykorzystanie historii generuje konkretne polityczne konsekwencje. W prozachodniej Gruzji po Rewolucji Róż zmiana dyskursu jest powierzchowna.

Po drugie marksizm jako źródło idei oraz pamięć i zapomnienie. Krytycy spojrzenia postkolonialnego na przestrzeń postsowiecką wskazują również na marksowskie i marksistowskie podłoże teorii. Jednakże Leela Gandhi słusznie podkreśla fascynację części teoretyków spadkobierstwem marksizmu oraz ambiwalentną wzajemną relacją (Krzysztan, 2016). Postkolonializm jest konkretną polityczną propozycją, która wiąże się z odrzuceniem oków przez rezygnację z przystosowania do uniwersalnych wzorców. Marksizm w formie upaństwowionej przeczy w znacznej mierze temu postulatowi, wraz z rozwojem Bloku Wschodniego stając się imperialistyczną i generalną teorią (Gandhi, 2008, s. 30). Inny zarzut dotyczy jednoznacznej roli ideologii w rozwoju procesów i struktur kolonialnych. Potencjalnie mamy do czynienia z sytuacją, w której kat zostaje własnym sędzią. Należy jednak rozgraniczyć naukowe rozumienie teorii marksistowskich, używanych jedynie na gruncie teoretycznym, od ich praktycznego zastosowania. Pragmatyczna polityczna implementacja z konieczności dziejo- 
wych i strukturalnych zmuszona jest reinterpretować i dostosowywać założenia oparte na wnioskach popartych zupełnie inną egzemplifikacją. Odrzucenie marksizmu jako przydatnego narzędzia interpretacji związane jest $\mathrm{z}$ warstwą narracyjnej reprezentacji pamięci i historii w przestrzeni politycznej. Brak krytyki dialektycznej ma konsekwencje w postaci konieczności przyswojenia jednoznacznej narracji o przeszłości. W efekcie polityczność staje się wydarzeniem antagonistycznym i zarzewiem konfliktów etnopolitycznych ${ }^{10}$.

Myśląc o swojej ojczyźnie, Milan Kundera pisał o wpływie pamięci na bieżące wydarzenia społeczno-polityczne, co przywołał George Schöpflin: „To ostrzeżenie, co się dzieje, gdy społeczeństwo zaniedbuje przeszłość, tym samym nie mogąc zmierzyć się z przyszłością i stając się więźniem w żelaznej klatce wiecznej teraźniejszości" (Schopflin, 2000, s. 75). Ta krótka sentencja z Nieprawdopodobnej lekkości bytu jest dobrą metaforą korzeni konfliktów w postkolonialnej Gruzji. Tradycja wymyślona, pamięć i reprezentacje ${ }^{11}$ przeszłości są esencją Kaukazu, niezbywalną w analizie. Kamil Janicki stwierdza, że nikt nie jest bardziej winny eskalacji konfliktów na Kaukazie Południowym od profesjonalnych historyków i okazjonalnych dzierżawców mitów (Janicki, 2009, ss. 95-99). Pamięć, kiedy staje się instrumentalnym narzędziem w budowaniu nowego postkolonialnego dyskursu, przekształca się w obosieczną broń. W przypadku Gruzji jest elementem politycznej kalkulacji i częścią narracji populistycznej, która staje na drodze rekonstrukcji. Dotyczy to zarówno działań byłej metropolii wobec Gruzji, jak też polityki hegemona lokalnego - Gruzji wobec republik secesjonistycznych i mniejszości etnicznych.

10 Osobnym zagadnieniem jest rozważanie nad kwestią „nieuniknioności” konfliktów w Abchazji i Osetii Południowej. Jeśli przyjąć, że na poziomie pierwotnym tożsamości opierają się na antagonizmie (Mouffe, 2008, ss. 24-26), a ten może być jedynie politycznie regulowany, wówczas system opresyjny ZSRS, zamroził tylko konflikty o długiej historii. Rozpad samego imperium był tylko ich bezpośrednią przyczyną.

11 Zapis jest celowy, co ma podkreślać wieloznaczność pojęcia reprezentacji w humanistyce (Zob. np.: Ricouer, 2012). 


\section{SCHIZOFRENICZNA POSTKOLONIALNA DWOISTOŚĆ DOŚWIADCZENIA. ABCHAZJA}

Kolejnym uwarunkowaniem pozornego ograniczenia jest kwestia struktury imperium. Teoria postkolonialna opiera się w głównej mierze na krytycznym rozliczeniu dziedzictw imperiów brytyjskiego i francuskiego. Hegemon, przestrzeń kolonizująca, jest jasno określona na przestrzeni dziejów, metropolia jest oczywista, a jej geograficzne i kulturowe umiejscowienie nie podlega rozważaniom, będąc przyjmowane aksjomatycznie. Metropolitalna Francja i Wielka Brytania jest dalekim centrum, a władza objawia się przemocą i imperialną symboliką. Kontynentalność i struktura formalna sprawia, że przykład ZSRS nie jest już tak oczywisty. Teoretycznie antyimperialna retoryka imperium wynikająca bezpośrednio z ideologicznego osadzenia w wypaczonej interpretacji marksizmu, stanowi barierę dla dokładnego określenia granicy między centrum i peryferiami, co wzmaga jeszcze internacjonalizm oparty na postulatywnej równości. Kłopotliwe jest jednak tożsame traktowanie obszarów, które zostały włączone w przestrzeń ZSRS w schedzie po Imperium Rosyjskim, oraz tych, które stały się jego częścią w wyniku późniejszej ekspansji. Innym jeszcze problemem są obszary formalnie nigdy niebędące częścią ZSRS, jak środkowoeuropejskie kraje satelickie, które także zależne są zarówno w dyskursie naukowym, jak też publicystycznym, od dziedzictwa byłego hegemona. Innymi słowy inaczej traktowana być powinna Syberia, inaczej Polska, a jeszcze inaczej Gruzja. Jest to argument powierzchowny, biorąc pod uwagę chociażby ogromną odmienność dependentnych obszarów byłego Imperium Brytyjskiego (np. Irlandia i Kenia). Jednocześnie siłą myśli postkolonialnej jest jej niespotykana wręcz pozytywna relatywność, a co za tym idzie możliwość komparatystyki przestrzeni tradycyjnie nieprzystawalnych. Jednocześnie kontynentalność w znacznej mierze wpływa na niejednoznaczność granic (zarówno tych fizycznych, jak i metaforycznych), co zaobserwować można w postsowieckich konfliktach.

Drugą barierą postkolonializmu, powiązaną ze schizofrenicznym doświadczeniem Gruzji, miałaby być struktura polityczna. Jej pozostałości wyraźnie kształtują rzeczywistość polityczną, również współczesną (Coene, 2011, ss. 133-151). W tym kontekście Gruzja nastręcza badaczowi problem wynikający z tej niejednoznaczności. Formalnie system konstytucyjny ZSRS wszystkie republiki autonomiczne i ich mieszkańców stawiał na równi, jednak obserwacja styków międzyetnicznych w imperium pozwala na stwierdzenie, że w skostniałej strukturze istniała wyraźna nieformalna stratyfikacja narodowościowa (Snyder, 
2015). W pierwszej kolejności premiowała ona nacje słowiańskie (Rosjan, Ukraińców i Białorusinów), następnie Ormian, Gruzinów, Mołdawian i nacje bałtyckie, by na końcu umieszczać nacje muzułmańskie, małe ludy autochtoniczne Kaukazu i Syberii oraz Dalekiego Wschodu. Andrzej Furier wskazuje na nieoczywistość pozycji samych Gruzinów (ich uprzywilejowanie) w ramach stosunku podporządkowania (Furier, 2000, ss. 120-128). Jeśli uznamy, że granice między peryferiami nie są jasne, to konieczne jest podkreślenie pewnej uprzywilejowanej pozycji Gruzinów w strukturze ZSRS, zwłaszcza w schyłkowym okresie imperium, w zestawieniu z pozycją Abchazów i Osetyjczyków ${ }^{12}$. Zatem za „centrum" kolonialne uznajemy Moskwę i Rosjan, z jednoczesnym zastrzeżeniem płynności kryterium. W połączeniu z tożsamością wyjątkowości, a więc przez wytworzenie wykluczającej narracji, płynność imperium i struktura polityczna odpowiadają za eskalację konfliktów. Teleologia wykształcenia tożsamości wyjątkowości w spleceniu z konkretnymi narracjami mnemonicznymi budowana była jako postkolonialna opozycja wobec byłego hegemona. Jednakże etniczne zróżnicowanie i wieloznaczność sporów pozwoliły na wykształcenie drugiego poziomu doświadczenia kolonialnego, w którym Gruzja staje się lokalnym imperium i hegemonem kolonialnym. Historia przełomów jest skomplikowana (Zob. np.: Ayoob \& Ismayilov, 2015; Coppieters, 2004; Czachor, 2014; Waal, 2010), na potrzeby więc tekstu posłużymy się przykładem Abchazji.

Koniec ZSRS przyspieszył proces odbudowywania poranionych i podległych tożsamości etnicznych. Jednym z najważniejszych elementów tej rekonstrukcji był język, mocno spleciony z walką o własną autonomię, a w efekcie jeden z podstawowych powodów eskalacji postkolonialnych konfliktów. Bruno Coppieters stwierdza: „na poziomie lokalnym proces [destalinizacji] spowodował ostrą rywalizację między gruzińskimi i abchaskimi elitami politycznymi o kontrolę nad instytucjami państwowymi w Abchazji” (Coppieters, 2004, ss. 194-195). Faktyczna prawna rozgrywka wokół autonomicznego statusu języka miała silne podłoże kulturowe, istotne w dyskusji postkolonialnej. Ze względu na autonomiczny status Abchazji w ramach gruzińskiej SRS standardem były abchaskie oskarżenia o „gruzinizację”, przy jednoczesnym współdzielonym doświadczeniu „sowietyzacji” lub „rusyfikacji”. Jednocześnie Abchazi byli nadreprezentowani

12 Wynika to przede wszystkim z silnej pozycji Szewardnadzego piastującego funkcję ministra spraw zagranicznych ZSRS za czasów Michaiła Gorbaczowa. Jego rola miała znaczny wpływ na całkowite zlekceważenie i marginalizację procesów irredentyzmu Abchazów i Osetyjczyków, a w konsekwencji eskalację sporów etnicznych (Coene, 2011, ss. 151-152). 
w lokalnych strukturach, co skutkowało oskarżeniami ze strony gruzińskiej o wspieranie intensywnej rusyfikacji (Coene, 2011, s. 149; Coppieters, 2004, s. 195). Frederick Coene podkreśla znaczenie konfliktów z lat 1957 i 1967, które były efektem niepożądanej adopcji gruzińskiego alfabetu jako obowiązującego drugiego po rosyjskiej grażdance. Ten nierówny status językowy do pewnego momentu uprzywilejowywał edukację oraz kulturę w języku gruzińskim (Janicki, 2009, ss. 147-152). Konsekwencje tego procesu oraz koniecznego wsparcia rusyfikacji i wynikającej z niej kreolizacji kultury można obserwować do dziś. Niewielki procent ludności kraju posługuje się abchaskim jako pierwszym językiem. Innym aktem polityczności doświadczenia kolonializmu była inicjatywa z 1978 roku, będąca próbą przywrócenia Abchazji statusu autonomicznego sprzed 1936 roku (samodzielna republika sowiecka) bądź włączenia Abchazji do rosyjskiego Kaukazu Północnego, co skończyło się zamieszkami w Tbilisi w 1981 roku (Coene, 2011, s. 149).

Lokalna samoświadomość Abchazów uwarunkowana historycznymi związkami z innymi autochtonicznymi nacjami północnego Kaukazu, szczególnie z Czerkiesami, powodowała na przestrzeni dziejów uzależnienia podwójną głęboką potrzebę i zaangażowanie w działania antysystemowe. Abchazi brali czynny udział w antyrosyjskich powstaniach, na pewien czas w większości przechodząc na islam (Clogg, 1999, s. 205). Jednocześnie dokonywane przez Gruzinów próby kulturowego ujednolicania przez marginalizację elementów abchaskiej tożsamości narodowej miały podwójny charakter, analogiczny do wielopoziomowego doświadczenia bycia subaltern opisywanego przez Spivak (1988, ss. 24-28). Coppieters opisuję tę zależność następująco: „[z]godnie z historiografią abchaską w okresie sowieckim występowało wiele przypadków opresji wobec Abchazów. Gruzini próbowali asymilować relatywnie małą społeczność abchaską przez politykę kultury i edukację oraz zmianę przekroju demograficznego republiki" (Coppieters, 2004, s. 194). Biorąc pod uwagę ideologiczne i nacjonalistyczne zaangażowanie historyków kaukaskich, należy traktować te opinie z dystansem, jednakże nie są one całkowicie pozbawione faktograficznej podstawy. 70 lat, które minęło- od czasu włączenia południowego Kaukazu do ZSRS, aż do rozpadu imperium - znacznie zmieniło strukturę narodowościową w Abchazji, marginalizując dotychczas dominujących Abchazów z korzyścią dla Gruzinów. Ponownie Coppieters: „[...] w strukturze ZSRS, zarówno Abchazi jak i Gruzini odczuwali silne zagrożenie dla ich kultur i narodowych tożsamości. Abchaski ruch narodowowyzwoleńczy sprzeciwiał się gruzinizacji ich republiki, podczas gdy Gruzini mobilizowali się przeciw rusyfikacji państwa. Te paralelne mobi- 
lizacje napędziły radykalne i bezkompromisowe poglądy w obu republikach" (Coppieters, 2004, s. 197). Podobny wniosek oskarżający kolonialne mechanizmy państwowe o podżeganie do nienawiści wyciąga Nino Berdzniszwili z Instytutu Gruzińsko-Abchaskiego: „[w] sowieckiej Gruzji wpajano nam nieufność do Abchazów. Oni widzieli w nas znienawidzonego starszego brata. Obraz wroga formował się przez dziesięciolecia" (Górecki, 2013, s. 144). Opór wobec regulacji kolonialnych Rosjan w Gruzji przyniósł kolonializm Gruzinów wobec Abchazów, a więc podwójne doświadczenie postkolonialne zdeterminowało eskalację konfliktów po rozpadzie ZSRS.

\section{OPRESYJNO-SYMBOLICZNA POLITYKA WOBEC MNIEJSZOŚCI ETNICZNYCH}

Ostatnim elementem dyskursu wokół aplikacji postkolonializmu do warunków gruzińskich jest zagadnienie ideologicznego charakteru projektów postkolonialnych. Postkolonializm nie jest tylko teoriami w naukowym sensie, ale również ideologią polityczną, gdyż przez opis i analizę kreuje intelektualne zaplecze dla wielopoziomowej zmiany zastanej „sytuacji kolonialnej i neokolonialnej”. Jest możliwością rozliczenia byłego kolonizatora i pociągnięcia go do moralnej i ekonomicznej odpowiedzialności. Jest także rewizją, rozliczeniem się z mitami oraz dziedzictwem skomplikowanej i trudnej przeszłości. Stanowić może barierę dla implementacji powyżej zdefiniowanego planu rozwojowego zarysowanego na początku lat 90. Będąc metodologicznie i konceptualnie przeciwieństwem jednako zerojedynkowych wizji kapitalizmu i socjalizmu, stanowiąc rozliczenie z humanistyką opartą na binarnych kartezjańskich opozycjach, postuluje nowy pogłębiony humanizm, tworzy tym samym jednak problem dla apologetycznej wizji jednorodnego świata (Loomba, 2011, ss. 194-212). W przestrzeni postsowieckiej jest więc barierą dla implementacji pewnych postulowanych zmian, zmierzających do neoliberalnego ujednoliconego modelu systemu-świata.

Jednocześnie postkolonialne strategie obrócone zostały niebezpiecznie w stronę ograniczania praw mniejszości etnicznych w Gruzji. To polityczno-społeczna przemoc symboliczna (Zob. Bourdieu \& Wacquant, 2001, ss. 131-170; Foucault, 1998) wobec mniejszości etnicznych, zarówno tych posiadających państwa tytularne (Armenia, Azerbejdżan), jak też mniejszych (Kistowie, Grecy pontyjscy, Turcy meschetyjscy, Awarowie, Udyni, Kurdowie, Jazydzi). Dotyczy to również kartwelskich subetnosów - Mengrelów i Swanów, którzy posiadając 
odrębne języki, mogą posługiwać się nimi jedynie w przestrzeni prywatnej. Tożsamość wyjątkowości jest jednocześnie tożsamością głębokiego wykluczenia. Na podstawie pogłębionych badań antropologicznych i wywiadów nieustrukturyzowanych możliwe jest przedstawienie wykluczenia postkolonialnego na podstawie sześciu kryteriów ${ }^{13}$ :

Jednym z podstawowych kryteriów odgórnie definiowanej przynależności jest kryterium religijne, a więc połączenie kwestii „bycia Gruzinem” i „bycia gruzińskim prawosławnym”. Wynika to z roli, jaką dla zachowania gruzińskiej odrębności odegrała w czasie istnienia ZSRS Cerkiew, oraz z politycznej siły Patriarchatu. Przemoc symboliczna objawia się wykluczeniem ze wspólnoty narodowej, mimo deklaracji wykluczanych o wolitywnej chęci bycia jej częścią. Etnia nie ma tu znaczenia, gdyż wyraźne syndromy wykluczenia dotyczą także np. muzułmańskich Gruzinów w Adżarii.

Drugie kryterium - językowe - występuje na dwóch poziomach. W przypadku Mengrelów i Swanów dotyczy niemożności posługiwania się jako oficjalnymi własnymi językami narodowymi. Jednocześnie następuje wykluczenie grup etnicznych z państwami tytularnymi, jak Azerbejdżanie w Kartli Południowej i Ormianie w Dżawachetii. Polityka państwowa utrudnia naukę w językach ojczystych, jednocześnie nie proponując alternatywnych możliwości nauki gruzińskiego.

Kolejne kryterium związane jest z etnicznymi źródłami nacjonalizmu (Zob. np. Smith, 2009). Model zaadoptowany zarówno na poziomie systemowym, jak i społecznym, nie zakłada możliwości bycia członkiem wspólnoty postkolonialnej, nie będąc członkiem etni.

Czwarte kryterium określa się mianem politycznego lub reprezentacji. Mniejszości etniczne są zmarginalizowane w gruzińskim systemie politycznym. Objawia się to przykładowo kształtem okręgów wyborczych, które pomyślane są tak, aby podtrzymywać niedoreprezentowanie mniejszości.

Zgodnie z piątym kryterium - pokoleniowym - istnieje istotna różnica pomiędzy tymi, którzy podlegali jeszcze socjalizacji sowieckiej, oraz nowym pokoleniem wyrastającym ze zmian po rozpadzie ZSRS. Efektem są wielowarstwowe konflikty międzypokoleniowe.

13 Wywiady z lokalnymi ekspertami, członkami wspólnot mniejszości oraz obserwacja uczestnicząca podczas badań terenowych prowadzonych w latach 2013-2016 w Gruzji i Armenii. 
Ostatnie obserwowalne kryterium wynika z nierówności ekonomicznych i wykluczenia społecznego, będącego jego efektem, powstałego w wyniku adaptacji neoliberalnych wzorów rozwoju.

Przenikanie się powyższych czynników prowadzi do pęknięć w postkolonialnej strukturze państwa, uniemożliwiając zrzucenie mentalnych oków i pełną dekolonizację. Opresyjna mentalność kolonizatora jest przez Gruzinów w schizofrenicznym dyskursie równie mocno pielęgnowana, jak też odrzucane są elementy własnej podległości wobec byłego hegemona.

\section{KONKLUZJE}

Podstawowymi celami powyższego tekstu było zastanowienie się nad potencjałem aplikacji analizy postkolonialnej w przestrzeni postsowieckiej oraz weryfikacja przez interpretację hipotezy o istnieniu dwoistego doświadczenia postkolonialnego sowieckich peryferii - Gruzji. Analiza studium przypadku, ze względu na wieloaspektowość wątków postkolonialnych, powinna być traktowana jedynie w kategoriach przyczynku do pogłębionej analizy struktur politycznych. Niemniej wydaje się uzasadnione twierdzenie, że aplikacja postkolonialnych narzędzi pozwala na szersze spojrzenie na polityczne i świadomościowe elementy postsowieckości, zwyczajowo ujmowane w paradygmacie studiów nad tranzycją, idei area studies bądź traktowanych jako osobny fenomen. Wskazany w tekście czteropoziomowy model interpretacji postsowieckiej przestrzeni postkolonialnej pozwala na potwierdzenie hipotezy o dwoistej naturze doświadczenia. Zmiana polityczna, która jest projektem niedokończonym (przyjęcie w 2003 roku proeuropejskiego i prozachodniego kursu polityki zagranicznej), wymaga pogłębionego zastanowienia nad koniecznością rozliczenia dziedzictwa kolonializmu, głównie w sferze, w której Gruzja może nosić miano ofiary, lecz przede wszystkim tam, gdzie staje się ona dzierżawcą przemocy, zarówno w sferze symbolicznej, jak i faktycznej.

\section{BibLIOGRAFIA:}

Adams, L. (2008). Can we apply postcolonial theory to Central Eurasia? Central Eurasian Studies Review, 7(1), 2-7.

Anderson, B. (1997). Wspólnoty wyobrażone: rozważania o źródłach i rozprzestrzenianiu się nacjonalizmu. (S. Amsterdamski, Tłum.). Kraków: Społeczny Instytut Wydawniczy. 
Ayoob, M., \& Ismayilov, M. (Red.). (2015). Identity and Politics in Central Asia and the Caucasus. London: Routledge.

Bal, M., \& Marx-MacDonald, S. (2002). Travelling Concepts in the Humanities: A Rough Guide. University of Toronto Press.

Batiashvili, N. (2012). The „Myth” of the Self: The Georgian National Narrative and Quest of Georgianess. W: A. Assmann \& L. Shortt (Red.), Memory and Political Change. New York: Palgrave Macmillan.

Beauvois, D. (2005). Trójkąt ukraiński: szlachta, carat i lud na Wołyniu, Podolu i Kijowszczyźnie, 1793-1914. InBook SA.

Beinorius, A. (2013). Orientalizm i dyskurs postkolonialny. Kilka problemów metodologicznych. Porównania, (12), 11-23.

Bourdieu, P., \& Wacquant, L.J.D. (2001). Zaproszenie do socjologii refleksyjnej. Warszawa: Oficyna Naukowa.

Broers, L. (2008). Filling the void: ethnic politics and nationalities policy in post-conflict Georgia. Nationalities Papers, 36(2), 275-304.

Brzezinski, Z., Sullivan, P., \& D.C.), C. for S. and I. S. (Washington. (1997). Russia and the Commonwealth of Independent States: Documents, Data, and Analysis. M.E. Sharpe.

Chakrabarty, D. (2011). Prowincjonalizacja Europy: myśl postkolonialna i różnica historyczna. (D. Kołodziejczyk, E. Domańska, \& T. Dobrogoszcz, Tłum.). Poznań: Wydawnictwo Poznańskie.

Chatterjee, P. (1993). Nationalist Thought and the Colonial World: A Derivative Discourse. Minneapolis: University Of Minnesota Press.

Chernetsky, V. (2007). Mapping Postcommunist Cultures: Russia and Ukraine in the Context of Globalization. Montreal: McGill-Queen's University Press.

Chioni Moore, D. (2001). Is the Post- in Postcolonial the Post- in Post-Soviet? Toward a Global Postcolonial Critique. Globalizing Literary Studies, 116(1), 111-128.

Clogg, R. (1999). Religion. W.G. Hewitt (Red.), The Abkhazians: A Handbook. Richmond: Curzon Press.

Coene, F. (2011). The Caucasus - An Introduction (Reprint edition). London; New York: Routledge.

Condee. (2009). The Imperial Trace: Recent Russian Cinema (1 edition). Oxford; New York: Oxford University Press.

Coppieters, B. (2004). Europeanization and Conflict Resolution: Case Studies from the European Periphery. Academia Press.

Czachor, R. (2014). Abchazja, Osetia Południowa, Górski Karabach. Geneza i funkcjonowanie systemów politycznych (T. 3). Wrocław: Biblioteka Instytutu Polsko-Rosyjskiego.

Etkind, A. (2011). Internal Colonization: Russia's Imperial Experience (1 edition). Cambridge, UK; Malden, MA: Polity.

Falkowski, M. (2010). Kształtowanie się gruzińskiej i azerskiej świadomości narodowej. Próba porównania. W M. Ząbek (Red.), Dylematy kaukaskie. Problemy narodowościowe i migracyjne. Warszawa: Wydawnictwo DiG. 
Foucault, M. (1998). Nadzorować i karać: narodziny więzienia. (T. Komendant, Tłum.). Warszawa: Wydawnictwo Aletheia.

Freire, M. R. (2008). The Russian Federation and the CIS. From superpower to besieged global power: restoring world order after the failure of the Bush doctrine, 155-175.

Furier, A. (2000). Droga Gruzji do niepodległości. Poznań: Zakład Badań Narodowościowych PAN.

Gandhi, L. (2008). Teoria postkolonialna. Wprowadzenie krytyczne. (J. Serwański, Tłum.). Poznań: Wydawnictwo Poznańskie.

Gawrycki, M. F., \& Szeptycki, A. (2012). Podporządkowanie - niedorozwój - wyobcowanie. Postkolonializm a stosunki międzynarodowe. Warszawa: Wydawnictwa Uniwersytetu Warszawskiego.

Górecki, W. (2013). Abchazja. Wołowiec: Wydawnictwo Czarne. Pobrane z: http://www. empik.com/abchazja-gorecki-wojciech,p1066655805,ksiazka-p.

Hladík, R. (2011). A Theory's Travelogue: Post-Colonial Theory in Post-Socialist Space. Teorie vedy/Theory of Science, XXXIII(4), 561-590.

Janicki, K. (Red.). (2009). Źródła nienawiści. Konflikty etniczne w krajach postkomunistycznych. Kraków-Warszawa: Instytut Wydawniczy ERICA.

Janion, M. (2003). Niesamowita słowiańszczyzna. Konteksty: polska sztuka ludowa: antropologia kultury, etnografia, sztuka, 57(1-2 (260-261)). Pobrane z: http://yadda. icm.edu.pl/yadda/element/bwmeta1.element.dl-catalog-bbf9a126-e80d-435f-87ee9f111f015b90.

Kakachia, K., \& Minesashvili, S. (2015). Identity politics: Exploring Georgian foreign policy behavior. Journal of Eurasian Studies, 6(2), 171-180. https://doi.org/10.1016/j. euras.2015.04.002.

Kroutvor, J. (1998). Europa Środkowa: anegdota i historia. Warszawa: Świat Literacki. Pobrane z: https://merlin.pl/europa-srodkowa-anegdota-i-historia-josef-kroutvor/ $1323178 /$.

Krzysztan, B. (2016). Problem z prze-pisaniem. Teoretyczne podstawy refleksji postkolonialnej a zagadnienie postkomunizmu. Kultura i Edukacja, 1(111), 101-114.

Kuzio, T. (2002). History, Memory and Nation Building in the Post-Soviet Colonial Space. Nationalities Papers, 30(2), 241-264.

Lenin, V. I. (1999). Imperialism: The Highest Stage of Capitalism. Resistance Books.

Loomba, A. (2011). Kolonializm/postkolonializm. (N. Bloch, Tłum.). Poznań: Wydawnictwo Poznańskie.

Memmi, A., \& Sartre, J.-P. (2013). The Colonizer and the Colonized. (H. Greenfeld, Tłum.). Plunkett Lake Press.

Michaels, P. (2004). Prisoners of the Caucasus: From Colonial to Postcolonial Narrative. Russian Studies in Literature, 40(2), 52-77.

Miłosz, C. (2009). Zniewolony umysł. Kraków: Wydawnictwo Literackie. Pobrane z: http:// www.wydawnictwoliterackie.pl/ksiazka/1804/Zniewolony-umysl---Czeslaw-Milosz.

Morozov, V. (2015). Russia's Postcolonial Identity: A Subaltern Empire in a Eurocentric World (2015 edition). Palgrave Macmillan. 
Mouffe, C. (2008). Polityczność. Warszawa: Wydawnictwo Krytyki Politycznej. Pobrane z: http://www.krytykapolityczna.pl/Przewodniki-Krytyki-Politycznej/Politycznosc-Przewodnik-Krytyki-Politycznej/menu-id-104.html.

Nodia, G. (1998). The Georgian Perception of the West. W B. Coppieters, A. Zverev, \& D. Trenin (Red.), Commonwealth and Independence in Post-Soviet Eurasia. London: Frank Cass Publishers.

Pliszczyńska, O. (2010). Polityka „niebezpieczeństwa” Gruzji. Instytut Europy Środkowo-Wschodniej.

Racevskis, K. (2005). Edward Said and Michel Foucault: Affinities and Dissonances. Research in African Literatures, 36(3), 83-97.

Riabczuk, M. (2015). Ukraina. Syndrom postkolonialny. Wojnowice: KEW. Pobrane z: http://www.empik.com/ukraina-syndrom-postkolonialny-riabczuk-mykola, p1110267381,ksiazka-p.

Ricouer, P. (2012). Pamięć, historia, zapomnienie. (J. Margański, Tłum.). Kraków: UNIVERSITAS.

Robson, M. (2006). Estimating Russia's Impact on the Economic Performance of the Commonwealth of Independent Stated since 1991: The Cases of the Kyrgyz Republic, Tajikistan, Armenia, Georgia and Ukriane (Policy Paper No. 16). London: Overseas Development Institute.

Said, E. W. (1979). Orientalism (1 ${ }^{\text {st }}$ Vintage Books ed edition). New York: Vintage.

Said, E. W. (2005). Orientalizm. (M. Wyrwas-Wiśniewska, Tłum.). Poznań: Zysk i S-ka. Schopflin, G. (2000). Nations, Identity, Power. New York: NYU Press.

Smith, A. D. (2009). Ethno-symbolism and Nationalism: A Cultural Approach. Routledge. Smola, K., \& Uffelmann, D. (2016). Postcolonial Slavic Literatures After Communism (New edition). New York: Peter Lang GmbH, Internationaler Verlag der Wissenschaften.

Snyder, T. (2015). Skrwawione ziemie. Europa między Hitlerem a Stalinem. Wydawnictwo Znak. Pobrane z: http://www.znak.com.pl/kartoteka,ksiazka,6832,Skrwawione-ziemie

Sokov, N. (2005). The Withdrawal of Russian Military Bases from Georgia: Not Solving Anything (Policy Paper No. 363).

Sowa, J. (2011). Fantomowe ciało króla. Peryferyjne zmagania z nowoczesna forma (T. 90). Kraków: UNIVERSITAS.

Spivak, G. C. (1988). Can the Subaltern Speak? W C. Nelson \& L. Grossberg (red.), Marxism and the Interpretation of Culture. Urbana: University of Illinois Press.

Spivak, G. C. (2006). Krytyka postkolonialnego rozumu. W stronę historii zanikającej współczesności. W: A. Burzyńska \& M. P. Markowski (Red.), Teorie literatury XX wieku. Antologia. Kraków: Wydawnictwo Znak.

Staniszkis, J. (2006). Postkomunizm Próba Opisu. Gdańsk: słowo/obraz terytoria. Pobrane z: http://www.empik.com/postkomunizm-proba-opisu-staniszkisjadwiga,320549,ksiazka-p. 
Śpiewak, P. (2005). Pamięć po komunizmie / Instytut Książki. Gdańsk: słowo/obraz terytoria. Pobrane z: http://www.instytutksiazki.pl/ksiazki-detal,literaturapolska,1888,pamiec-po-komunizmie.html.

Thompson, E. M. (2000). Trubadurzy imperium: literatura rosyjska i kolonializm (T. 8). Universitas. Pobrane z: http://scholar.google.com/scholar?cluster=1676 6640048045645426\&hl=en\&oi=scholarr.

Tischner, J. (1992). Etyka solidarności i homo sovieticus. Kraków: Społeczny Instytut Wydawniczy Znak.

Tlostanova, M. V. (2012). Postsocialist $\neq$ Postcolonial? On Post-Soviet Imaginary and Global Coloniality? Journal of Postcolonial Writing, 48(2), 130-142.

Tlostanova, M. V. (2015a). Between the Russian/Soviet Dependencies, Neoliberal Delusions, Dewesternizing Options, and Decolonial Drives. Cultural Dynamics, (27), 267-283.

Tlostanova, M. V. (2015b). Can the Post-Soviet Think? On Coloniality of Knowledge, External Imperial and Double Colonial Difference. Intersections" East European Journal of Society and Politics, 1(2), 38-58.

Todorova, M. (2008). Bałkany wyobrażone, tłum. P. Szymor i M. Budzińska, Wołowiec, 251.

Trzaskowski, P. (2009). Gruzińska „rewolucja róż”: Zachód i idea Zachodu a przemiany polityczne w Gruzji. Warszawa: Fundacja Studiów Międzynarodowych.

Uffelmann, D. (2013). Theory as Memory Practise: The Divided Discourse on Poland's Postcoloniality. W: U. Blacker, A. Etkind, \& J. Fedor (Red.), Memory and Theory in Eastern Europe. New York: Palgrave Macmillan.

Waal, T. de. (2010). The Caucasus: An Introduction. Oxford University Press.

wa Thiongoo, N. (2011). Decolonising the Mind: The Politics of Language in African Literature. London; Portsmouth, N.H.: James Currey Ltd / Heinemann.

Zadura, D. (2010). Naród w tygrysiej skórze. Tożsamość narodowa Gruzinów w dobie „rewolucji róż”.W: M. Ząbek (red.), Dylematy kaukaskie. Problemy narodowościowe i migracyjne. Warszawa: Wydawnictwo DiG.

Zarycki. (2014). Ideologies of Eastness in Central and Eastern Europe. Abingdon, Oxon; New York: Routledge.

Zinoviev, A. (1984). Homo sovieticus. London: Polonia. 